\title{
INTERLEUKIN MRNA CHANGES IN MAST CELLS STIMULATED BY TSL-1 ANTIGENS
}

\author{
ARIZMENDI N.*, YÉPEZ-MULIA L.*, CEDILLO-RIVERA R.*, ORTEGA-PIERRES M.G.**, MUÑOZ O.*, \\ BEFUS D.*** \& ENCISO-MORENO J.A.*
}

\section{Summary :}

In this work we analyzed by RT-PCR, the mRNA changes for IL-4, IL-10, TNF and IFN ( induced by TSL-1 antigens in a rat mast cell line (HRMC) with mucosal characteristics. The data obtained showed an increase of 65 and $52 \%$ in mRNA expression for Il-4 and TNF respectively and a decrease of 59 and $55 \%$ in mRNAs for IFN $\gamma$ and IL-10. Our results suggest that TSL- 1 antigens induce the release from MC of regulatory molecules, such as II-4 by an lgE independent mechanism. Our data also provides important information related to the ability of $M C$ to participate not only in the effector phase against the infectious agents, but also in the orchestration of the immune response by the host against parasites.

KEY WORDS : mast cell, activation, TSL-1 antigens, RT-PCR, Trichinella spiralis.

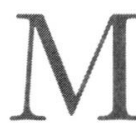
ast cell (MC) degranulation at sites of invasion by pathogens has a protective role for the host. In this regard, MC are phagocytic towards bacteria and the release of TNF by MC induces the recruitment of neutrophils to the site of Klebsiella pneumoniae infection. It has been well documented that $\mathrm{MC}$ can be activated by direct contact with other bacteria such as E. coli and also by protozoa parasites such as Leishmania major and L. infantum, making them important elements in innate immunity (Bidri et al., 1997; Malaviya et al., 1999). Recently, we have demonstrated IgE independent activation of MC by Trichinella spiralis antigens (TSL-1 antigens) evaluating as activation markers the release of histamine, protease 5 (P5) and TNF $\alpha$ (Arizmendi et al., 1997). Particularly, peritoneal MC (PMC) obtained from non-sensitized rats, showed the maximum release of $\mathrm{P} 5$ and histamine when $30 \mathrm{ng} / \mathrm{ml}$ of TSL-1 antigens were used. On the other hand, it has been suggested that interleukins (mainly IL-4) produced by MC in response to helminthic antigens can actively participate in the early induction of Th2 type response in intestinal helminthic infections (Romagnani, 1992). Therefore, we deter-

\footnotetext{
* UIMEIP-Pediatría,CMN Siglo XXI, IMSS, México.

** Depto. Genética y Biología Molecular, CINVESTAV-IPN, México.

*** PCBRG, University of Alberta, Canada.

Correspondence: Lilian Yepez-Mulia.

Tel.:52(5)-627-6900 ext 3205 - Fax: 52(5)-627-6949.

e-mail: lilianyepez@yahoo.com
}

mined if the direct activation of MC by TSL-1 antigens, induce changes in mRNA expression of specific MC interleukin mRNAs, mainly IL-4, IL-10, TNF and IFN $\gamma$.

\section{MATERIAL AND METHODS}

\section{PARASITES AND ANTIGENS}

spiralis (MSUS/MEX/91 CM-91) was maintained in Sprague Dawley rats and muscle larvae (ML) were recovered by acid-pepsin digestion (Dennis et al.,1970). Purification of TSL-1 antigens was carried out as recommended by Ortega-Pierres et al. (1989).

\section{HRMC CULTURES AND STIMULATION WITH TSL-1 ANTIGENS}

HRMC, a rat mast cell line, with characteristics of mucosal mast cell, was kindly provided by Dr. A. Froese, University of Manitoba, Canada. One $10^{6} \mathrm{HRMC}$ cells were incubated at $37^{\circ} \mathrm{C}$ in a humidified atmosphere containing $5 \% \mathrm{CO}_{2}$ in RPMI-1640 medium supplemented with $10 \%$ fetal bovine serum (FBS) for eight hours in the presence of $30 \mathrm{ng} / \mathrm{ml}$ of TSL- 1 antigens (surface antigens purified from T. spiralis ML). HRMC without treatment was included as negative control.

\section{RT-PCR ASSAYS}

Total RNA from HRMC cells stimulated with TSL-1 antigens was prepared following the procedure described by Chomcynski and Sacchi (1987). Two $\mu \mathrm{g}$ of total RNA were then converted to single stranded cDNA by using Expand RT enzyme, according to the provider's instructions (Boehringer Mannheim, Germany). PCR amplification was carried out using specific primers for rat IL-4, IL-10, TNF, IFN $\gamma$ and $\beta$ actin (Table I). The amplified products were separated by agarose gel electrophoresis and visualized under UV transilluminator by staining with ethidium bromide. The amplification products were quantified by densitometry (Genetools Program, Synoptics, Cambridge, 


\begin{tabular}{cll}
\hline Interleukin & \multicolumn{1}{c}{ Primers } \\
\hline \multirow{2}{*}{ IL-4 } & $\begin{array}{l}\text { Sense } \\
\text { Antisense }\end{array}$ & 5'CTGTAGAGAGCTATTGATGG3' \\
& 5'GACATGGAAGTGCAG3' \\
IL-10 & Sense & 5'CACTGCTATGTTGCCTGCTC3' \\
& Antisense & 5'TTCATGGCCTTGTAGACACC3' \\
TNF & Sense & 5'TACTGAACTTCGGGGTGATTGGTCC3' \\
& Antisense & 5'CAGCCTTGTCCCTTGAAGAGAACC3' \\
IFN $\gamma$ & Sense & 5'AGCTCTGAGACAATGAGTG3' \\
& Antisense & 5'CCAGAATCAGCACCGACTC3' \\
$\beta$ actin & Sense & 5'ATGGATGACGATATCGCTG3' \\
& Antisense & 5'GATTCCATACCCAGGAAGG3' \\
\hline
\end{tabular}

Table I. - PCR primers specific for rat IL-4, IL-10, TNF, IFN $\gamma$ and $\beta$ actin.

United Kingdom) and relative values were determined by normalizing to $\beta$ actin PCR amplification product.

\section{RESULTS}

T The PCR amplification products from each interleukin (Fig. 1) were analyzed by densitometry, and values were normalized to $\beta$ actin amplification product (these data are representative of three experiments). These values were compared to the negative control as a percentage of increase or decrease (Table II). From this analysis, we observed an increase of 65 and $52 \%$ in mRNA expression for IL- 4 and TNF

\begin{tabular}{|c|c|c|c|c|}
\hline \multirow[b]{2}{*}{ Interleukins } & \multicolumn{2}{|c|}{ Optical density } & \multicolumn{2}{|c|}{ Percentage } \\
\hline & Untreated & TSL-1 treated & Increase & Decrease \\
\hline IL-4 & 496 & 758 & 65 & \\
\hline IL-10 & 544 & 248 & & 55 \\
\hline TNF & 485 & 742 & 52 & \\
\hline IFN- $\gamma$ & 631 & 259 & & 59 \\
\hline
\end{tabular}

Treated cells were exposed to TSL- 1 antigens $(30 \mathrm{ng} / \mathrm{ml})$ for $8 \mathrm{~h}$. All results were normalized according to $\beta$-actin densitometric values.

Table II. - Densitometric analysis of interleukin mRNA changes in MC induced by TSL-1 antigens.

respectively and a decrease of 59 and $55 \%$ in mRNAs for IFN $\gamma$ and IL-10 respectively.

\section{DISCUSSION}

M ast cell populations from different species and sites can be activated by secretagogues arising from a variety of sources. It has been suggested that MC play an important role in both acquired and innate immune responses in the host. Recently it has been demonstrated that MC can release TNF as a result of direct activation by bacterial and parasite antigens (Bidri et al., 1997; Malaviya et al., 1999). In this regard, we have previously demonstrated that PMC are activated by TSL- 1 antigens by an IgE independent mechanism and that as a result of this

\section{INTERLEUKIN}

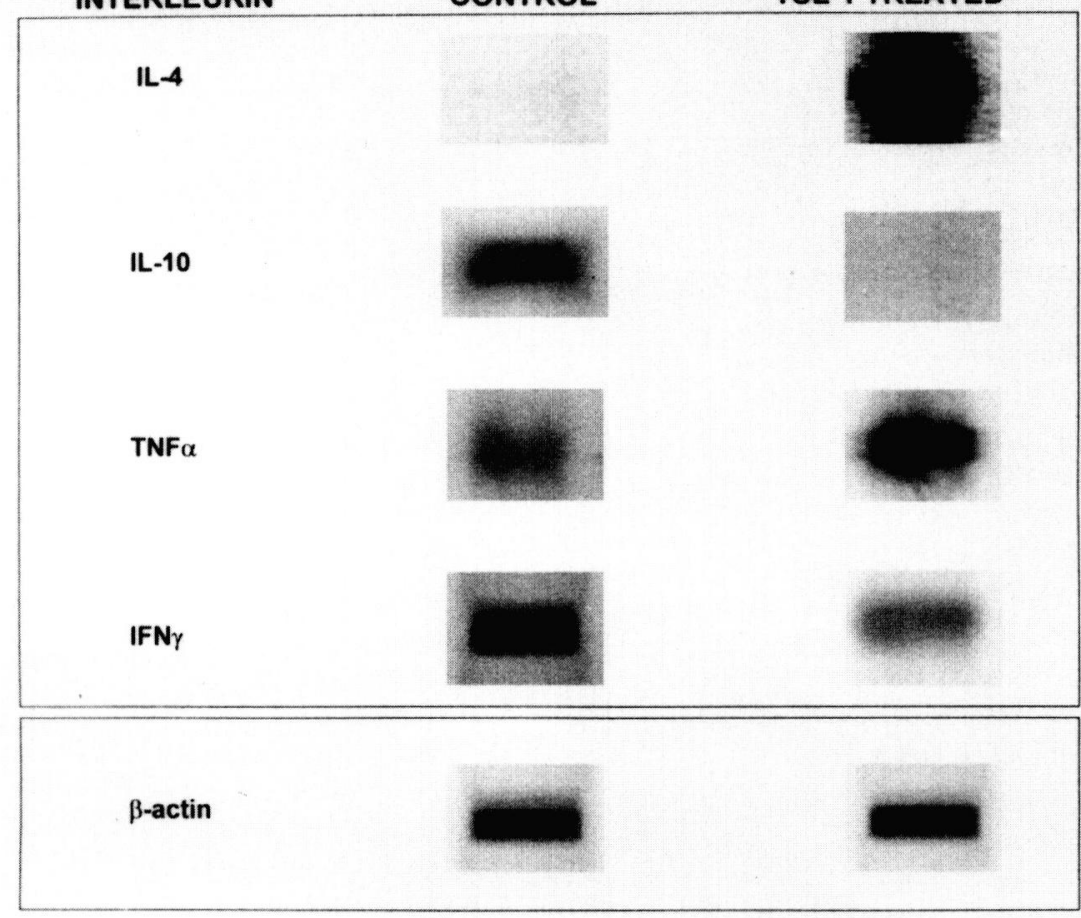

Fig. 1. - RT-PCR analysis of interleukin mRNA changes induced in MC by TSL-1 antigens. 
activation MC release histamine, P5 and TNF (Arizmendi et al., 1997). On the other hand, given the type of ILs produced by MC and their possible release after direct contact with parasite antigens, these cells can also participate not only in the effector phase against the infectious agents, but they can regulate the immune response that is induced in the host against them. Thus, we demonstrated that MC can increase their mRNA levels for IL- 4 and TNF, whereas they decrease mRNA levels for IFN $\gamma$ and IL-10 by direct contact with TSL-1 antigens. The results obtained in this study provide important evidence related to the ability of $\mathrm{MC}$ to produce mRNA for regulatory molecules, such as IL-4, suggesting that $\mathrm{MC}$ could participate in the induction of a preferential TH2 type immune response during intestinal infections by helminths. Together these results place the MC as an important factor in innate immunity.

\section{ACKNOWLEDGEMENTS}

TT Te are grateful to Arturo Pérez Taylor R. for excellent technical assistance. This work was supported by CONACyT, Mexico grant num-

ber: 32677-M.

\section{REFERENCES}

ARIZMEndi N., CASAS O., YePEZ-MUlia L., CEDillo R., ORTEGAPIERRES M.G., MUÑOZ O., BEFUS D. \& ENCISO-MORENO j.A. Activation of mast cells by trichinella spiralis antigens through an independent lge mechanism. In: Trichinellosis, proceedings of the $9^{\text {th }}$ internacional conference on trichinellosis. Ortega-Pierres M.G., Gamble H.R., Wakelin D., Ed. cd. de Mexico, Mexico, 1997, pp. 397-404.

Bidri M., Vouldoukis l., Mossalayi M.D., Debré P., Gulllosson J.J., Mazier D. \& Arock M. Evidence for direct interaction between mast cells and Leishmania parasites. Parasite Immunology, 1997, 19, 475-483.

Chomczynski P. \& SACCHI N. Single-step method of RNA isolation by acid guanidium Thiocyanate-Phenol-Chioroform extraction. An. Biochem., 1987, 162, 156-159.

Dennis D.T., Despommier D.D. \& Davis N. Infectivity of the newborn larvae of Trichinella spiralis in the rat. Journal of Parasitology, 1970, 56, 974.

Malaviya R., Gao Z., Thankavel K., van der Merwe PA. \& ABRAHAM SN. The mast cell tumor necrosis factor $\alpha$ response to FimH-expressing Escherichia coli is mediated by the giycosylphosphatidylinositol-anchored molecule CD 48 . Proc. Natl. Acad. Sci. USA, 1999, 96, 8110-8115.

Ortega-Pierres G., Muñiz E., Coral-Vázquez R. \& Parkhouse R.M.E. Protection against Trichinella spiralis induced by purified stage-specific surface antigens of infective larvae. Parasitol. Res., 1989, 75, 563.

ROMAGNANI S. Induction of TH1 and TH2 responses: a key role for the natural immune response? Immunology Today, 1992, 13, 379-381. 